\title{
The Sociology of Education in Brazil Today
}

\author{
La sociología de la educación en Brasil hoy \\ A sociologia da educação no Brasil hoje
}

Amurabi Oliveira y Camila Ferreira da Silva ${ }^{1}$

\begin{abstract}
The field of sociology of education in Brazil is marked by a deep institutional fragmentation, being developed both in the Postgraduate Programs in Social Sciences/Sociology and in Education. With the expansion of higher education and other transformations in education systems, Sociology of Education has expanded and gained space in the research agenda of Brazilian sociology. In this article we analyze its development in a recent period, considering the research areas of the postgraduate programs in sociology, as well as its academic production in journals in the last four years. We observed the solidification of education as an area of research in the field of Brazilian sociology, as well as a growing interest in research involving primary and secondary education.
\end{abstract}

Keywords

Sociology of education, Brazilian sociology, academic field.

\section{Resumen}

El campo de la sociología de la educación en Brasil está marcado por una profunda fragmentación institucional, desarrollándose tanto en los Programas de Postgrado en Ciencias Sociales/Sociología como en Educación. Con la expansión de la enseñanza superior y otras transformaciones en los sistemas de enseñanza, la Sociología de la Educación se ha expandido y ha ganado espacio en la agenda de investigación de la sociología brasileña. En este artículo analizamos su desarrollo en un período reciente, considerando las áreas de investigación de los programas de postgrado en sociología, así como su producción académica en los últimos cuatro años. Observamos la solidificación de la educación como área de investigación en el campo de la sociología brasileña, así como un creciente interés por las investigaciones involucrando la educación primaria y secundaria.

\section{Palabras clave}

Sociología de la educación, sociología brasileña, el campo académico.

\section{Resumo}

O campo da sociologia da educação no Brasil é marcado por uma profunda fragmentação institucional, desenvolvendo-se tanto nos Programas de Pós-Graduação em Ciências Sociais/Sociologia quanto em Educação. Com a expansão do ensino superior e outras transformações nos sistemas de ensino, a Sociologia da Educação tem se expandido e ganhado espaço na agenda de pesquisa da sociologia brasileira. Neste artigo nós analisamos seu desenvolvimento em período recente, considerando as áreas de pesquisa dos programas de pós-graduação em sociologia, bem como sua produção acadêmica nos últimos quatro anos. Observamos a solidificação da educação como área de pesquisa no campo da sociologia brasileira, assim como um crescente interesse pelas pesquisas envolvendo a educação primária e secundária.

\section{Palabras chave}

Sociologia da educação, sociologia brasileira, campo acadêmico.

\section{Cómo citar/Citation}

Oliveira, Amurabi y Silva, Camila (2020). The Sociology of Education in Brazil Today. Revista de Sociología de la Educación-RASE, 13 (1), $36-51$. http://dx.doi.org/10.7203/RASE.13.1.14658.

1 Amurabi Oliveira, Universidade Federal de Santa Catarina, amurabi_cs@hotmail.com; Camila Ferreira da Silva, Universidad Federal del Amazonas, ferreira.camilasilva@gmail.com. 


\section{Introduction}

The Sociology of Education (SE) as a disciplinary field in Brazil has a substantial flow and a close relationship with the area of Education since its inception. These issues are evidenced when considering elements such as the inauguration of the first chairs of sociology in the Normal Schools ${ }^{2}$, still in the late 1920s; the intense presence of sociology in the educational reforms of the first half of the twentieth century (Meucci, 2015); and the relevance of the Brazilian Center for Educational Research in the 1950s, as evidenced by the specialized literature (Neves, 2002, Martins \& Weber, 2010, Oliveira \& Silva, 2014, 2016; Almeida \& Hey, 2018) although it has not been fully consolidated as a successful experiment in the sense of forming the sociology of education as a policy science (Silva, 2002).

The institutional fragmentation that this path eventually established is expressed above all by the sociology of education produced in the Faculties of Education and by that presented in the Departments of Social Sciences/Sociology ${ }^{3}$ - dismemberment which also shows itself as a constitutive mark of this field, with emphasis on what was born out of the University Reform of 1968, with the advent of the Postgraduate Programs (PP) and the Faculties of Education, when, in the reading of Cunha (1992), is the germ of the peripheral position that the education came to occupy the agenda of Brazilian sociology.

It would escape from the scope of this article to retake this socio-historical reconstruction, primarily carried out by other authors. However, it is interesting to understand that the current scenario of the sociology of education in Brazil is mostly a reflection of this nonlinear and segmental process. We, therefore, question this current scenario through the analysis of recent production in the SE field.

It is important to point out that if we recognize the institutional fragmentation of the sociology of education, on the one hand, we understand that what is produced in this space in the various institutional areas constitutes relevant parts for the understanding of the field. However, we have made a methodological cut here that allowed us to advance in the discussion, focusing our analysis exclusively on the sociology of education developed in PP in social sciences, and more specifically in sociology.

The analysis of the data presented here is limited exclusively to the academic production disseminated through articles in journals in the last four years of evaluation of the Coordination of Improvement of Higher Education Personnel (CAPES), comprising a period from 2013 to $2016^{4}$, which would enable us to understand the recent movement of production and institutionalization of educational research in postgraduate programs in social sciences/sociology.

\section{Methodological note}

In previous work (Oliveira \& Silva, 2016), we conducted a survey in relation to the research areas, as well as with regard to the researchers dedicated to the sociology of education in sociology programs, promoting a combination of data obtained in the sucupira platform ${ }^{5}$ and lattes platform ${ }^{6}$. At the moment, the

2 Normal Schools are secondary education courses that are preparatory to the teaching profession, whose early experiences in Brazil date back to the first half of the 19th century. Until the beginning of the 20th century, they were the only spaces for teacher education in Brazil, which later became increasingly occupied by universities and non-university higher education institutions.

3 In Brazil the academic career of sociology develops at undergraduate level exclusively in social sciences courses, and at the graduate level in both masters and doctorates in social sciences as well as in sociology.

4 CAPES conducts a regular evaluation of all postgraduate programs in Brazil every four years, through which a grade is assigned on a scale of 1 to 7 for each program, of which 3 is considered the minimum grade for the program to function and 7 the grade of academic excellence. The last CAPES evaluation was carried out in 2017, comprising the period between 2013 and 2016.

5 Public platform in which data are available for all postgraduate programs in Brazil.

6 Public platform in which the $\mathrm{CVs}$ of the Brazilian researchers are available. 
data collected refer, on the one hand, to the research areas of the postgraduate programs in sociology, excluding social science programs, or hybrid programs1, and in a second movement, interested us bibliographic productions of these programs, disseminated through specialized journals.

It is attentive to the fact that we recognize here that the choice strictly for PP in sociology leads us to some limits in terms of the sample since undoubtedly there is a significant part of the production in the area of sociology of education that is also in PP in social sciences or hybrid programs. However, the choice of PP in sociology allows us to think more specifically that the educational issue is inserted in the agenda of sociology in the strict sense.

Regarding the bibliographic production, it is important to point out that the choice of prioritizing articles in journals, secondarily in our analysis the output in books, book chapters and annals of events, allows us to articulate the quantitative dimension in relation to the total volume of production with qualitative data, insofar as data are more readily available with regard to the qualitative evaluation of journals. Besides, it is also through journals that the process of internationalization of academic production can be captured more immediately, stressing this production with one of the most prominent issues that have been placed in the institutional evaluation of CAPES.

It is observed that the cut adopted allowed us to visualize the total production in journals of these programs, including there what had been produced by the faculty staff and students, besides the students graduated from the respective programs. It should be noted that the production of all PP was not observed, but only those that indicated the existence of research areas in dialogue with education to some degree. The work we carried out with the articles in question took place through the following steps: a) search, in the open data of the Sucupira Platform, for the files with the intellectual production of the PP strict sense 2013-2016; b) mapping articles published in journals of sociology programs with areas that establish dialogue with education (total of 2,500 articles), followed by separation of articles on education (total of 228 articles); c) search for articles on the internet and reading the abstracts for the construction of the categories of analysis; d) categorization, statistical organization and data analysis.

\section{The Research Areas}

The process of organizing PP through research areas allows us to capture how the various PP structure their research agendas, as well as which sets of activities they seek to make visible in the process of structuring their work.

In a survey carried out in the 1990s, Weber (1992) pointed to the small number of research area in education in the Brazilian sociology, in the PP in sociology, at that time there were only four programs (University of Brasilia, Federal University of Pernambuco, Federal University of Rio Grande do Sul, University Institute of Research of Rio de Janeiro) who had research areas in education. On the other hand, Sobral (2013) indicated that in 1999 there were research areas in this area in six programs (including social sciences and political sociology), namely: Federal University of Rio Grande do Norte, Federal University of Pernambuco, Federal University of Minas Gerais, University of São Paulo, Federal University of Santa Catarina and University of Brasília. In a more recent balance, Lima and Cortes (2013) point to the dispersion and diversity of research areas in PP in sociology/social sciences, in which 95 different research areas were classified, of which only four dedicated to the educational issue. 
When comparing these balances, we could indicate at first that there was a decrease in the participation of education in the research agenda of sociology, since the first balance refers to a scenario in which there were only 13 programs, while the second is inserted at a time when there were 53 programs.

However, we can also stress this data with more careful analysis, in which it also considers the summary of the research areas. In previous work (Oliveira \& Silva 2016), when we considered only the programs strictly in sociology, we had that 6 of them had specific of research areas in education, and four more indicated education as one of the topics to be researched in their areas of investigation. This scenario represents a significant expansion of the presence of education in the research agenda of Brazilian sociology, which can be explained, at least in part, by the increased access to formal schooling, especially to higher education - the academic world, not only a renewed concern to objectify education, but also a voluminous renewal of cadres with new professors and researchers, who eventually revolve themes, objects, theories, epistemologies, methodologies and research interests in general (Silva \& Alves, 2018).

This increase in the research areas dedicated to research in education in sociology programs also accompanies the movement of expansion of research groups in the National Council for Scientific and Technological Development $(\mathrm{CNPq})^{7}$ directory directed at the sociology of education (Oliveira \& Silva, 2014), so that we must recognize the existence of a diffuse and heterogeneous movement to expand the scope of sociological analysis on educational issues.

It is observed that, although the new survey took place after a brief period, there were a considerable number of PP that reformulated their research areas, incorporating issues related to education in their research agendas. In the current scenario, we have $6 \mathrm{PP}$ in sociology that have specific research areas on this subject, and these are its summaries:

Table I. Research areas in education in postgraduate programs in sociology

\begin{tabular}{|c|c|c|}
\hline INSTITUTION & AREA & SUMMARY \\
\hline Federal University of Piauí & State and Society: Labor, Education, Political actors and social inequalities & $\begin{array}{l}\text { A fundamental aspect of contemporary societies is the articulation between the worlds of work, } \\
\text { education and the way the various political actors deal with these social institutions. In this sense, } \\
\text { concepts such as social inequality, development, entrepreneurship and their relations with social } \\
\text { movements have implications for understanding the social changes that underlie our contemporary } \\
\text { social existence. The research of this area will have as a horizon the study of these concepts } \\
\text { and their social significations, especially in the Brazilian Northeast and Piaui, where the issues of } \\
\text { education, political mobilization and economic development can have profound influence on the } \\
\text { understanding of the processes that characterize the social inequality. }\end{array}$ \\
\hline University of Brasilia & Education, Science and Technology & $\begin{array}{l}\text { Research the new trends in education and science and technology policies. It tracks and evaluates } \\
\text { social policies and programs and their relationships with the national development process. It investi- } \\
\text { gates the conditions and new practices of production of scientific and technological knowledge, from } \\
\text { the context of globalization, the democratization of society and its impacts on Brazilian society. } \\
\text { It discusses the participation of different social actors in the elaboration of policies: the State, the } \\
\text { productive sector and the scientific community. It addresses emerging educational issues, such } \\
\text { as the diversification of higher education, the evolution of the postgraduate system, institutional } \\
\text { evaluation and the training of professional and scientific staff. }\end{array}$ \\
\hline University of Sũo Paulo & Sociology of Education & $\begin{array}{l}\text { The area of concentration encompasses the study of the relationships between cultural reproduction } \\
\text { and social reproduction, investigating educational institutions and practices in their articulations } \\
\text { with other spheres of social experience, both in contemporary societies in general and specifically } \\
\text { in Brazilian society. In this sense, it encompasses research on the history of institutional educational } \\
\text { systems, the constitution of the educational system in Brazil, academic experience in modern and } \\
\text { contemporary Brazil, education in sociological theory, relationships between school and social } \\
\text { classes, educational policies, the representations about school and education, the spaces and } \\
\text { subjects of educational practices external to school in modern societies. By exploring the social, } \\
\text { political and cultural dimensions of education, the studies developed within this area dialogue with } \\
\text { other sociological research themes such as work, youth, science, culture and democracy. }\end{array}$ \\
\hline
\end{tabular}
7 The National Council for Scientific and Technological Development is an institution linked to the Ministry of Science, Technology, Innovations, and Communi-
cations to encourage research in Brazil, responsible for the registration of researchers and research groups in Brazil. 


\begin{tabular}{|c|c|c|}
\hline INSTITUTION & AREA & SUMMARY \\
\hline Federal University of Goiás & Educational Practices in Contemporary Society & $\begin{array}{l}\text { This area of research privileges studies on the sociology of education, articulating the theo- } \\
\text { retical-methodological references of the social sciences to education; Studies on educational } \\
\text { policy, addressing the relations between state and society; Studies of educational practices and } \\
\text { contemporary subjects; Two school systems; Education and school culture; Educational and social } \\
\text { inequalities; Critical theory and education; Teaching and teacher training processes; The social role of } \\
\text { undergraduate and high school, as well as studies of experiences in non-formal education. }\end{array}$ \\
\hline $\begin{array}{l}\text { Federal University of } \\
\text { Pernambuco }\end{array}$ & Education, Work, Science and Technology & $\begin{array}{l}\text { It seeks to study the impact of recent technologies in the configuration of professional fields as } \\
\text { well as on the world of work. It also seeks to understand educational practices based on this impact. }\end{array}$ \\
\hline $\begin{array}{l}\text { Federal University of Rio } \\
\text { Grande do Sul }\end{array}$ & Society and Knowledge & $\begin{array}{l}\text { Analysis of the relationship between knowledge and society and its specificity in the contemporary } \\
\text { context. The focus is the understanding of the social character of the production of knowledge and } \\
\text { the investigation of the implications of the production and reproduction of knowledge for society. } \\
\text { The area includes the following research fields: Sociology of education (research on education, } \\
\text { educational policies, higher education); Sociology of science and technology (science, reflexivity, } \\
\text { role of technology and innovation); Sociological theory (epistemology, classical and contemporary } \\
\text { theory); Sociology of morality and religion (theoretical and empirical analyzes of moral phenomena, } \\
\text { religious phenomena and the relationship between both); Sociology of culture (research on culture } \\
\text { and knowledge). }\end{array}$ \\
\hline
\end{tabular}

Source: authors (2019).

Complementing the data in Table I, it is important to note that CAPES data also include the presence of a research area in education, called "Education, school and society", in the professional master's degree in Sociology in a national network of the Federal University of Ceará. However, at this moment we do not insert this PP and its area in our study by its professional nature and also by its new structuring since its operation began in 2018 , and for that reason, the information about its production, of course, is not yet included in the sucupira platform. Certainly, this experience will be the object of study of the field of production of the sociology of education in the future, providing questions about the expressions of this field in spaces such as professional masters.

Moving forward in the debate, we can observe, however, that the most significant increase in a short period occurred concerning the research areas that, although they do not already indicate in their titles the relation with education, point in their summaries the education as an interface. Below are the summaries of these eight other research areas.

\section{Table II. Research areas in education in postgraduate programs in sociology}

\begin{tabular}{|c|c|c|}
\hline INSTITUTION & AREA & SUMMARY \\
\hline $\begin{array}{l}\text { Federal University of } \\
\text { Sergipe }\end{array}$ & Intellectual Itineraries, Profession and Labor Market & $\begin{array}{l}\text { This research area involves studies that seek to understand the relations between knowledge and } \\
\text { society based on investigations of the conditions and social processes of knowledge production } \\
\text { and the formation of knowledge in its various forms (intellectual, artistic, cultural, scientific, etc.) } \\
\text { and the development of the education and higher education system, professional groups and } \\
\text { the labor market. It contemplates three thematic axes: a) Production of Knowledge, Sociology of } \\
\text { Intellectuals and Brazilian Social Thought; b) Processes of Formation of Professional Groups; Role } \\
\text { of Academic Degrees and knowledges in both legitimate and already consolidated professions and } \\
\text { careers (sociology, medicine, law, engineering, etc.), as well as in those new offices or those that } \\
\text { are not institutionalized and have low social credibility; c) Organization and Dynamics of the World } \\
\text { of Work, considering the recent transformations, the conflicts by posts and the disputes associated } \\
\text { with this process, especially those involving the teaching of sociology and the agents involved in } \\
\text { the relation between work and employment. }\end{array}$ \\
\hline $\begin{array}{l}\text { State University of Rio de } \\
\text { Janeiro }\end{array}$ & Inequalities, Social Mobility and Work & $\begin{array}{l}\text { The economic and social inequality remains a major problem in Brazil. Research on inequalities } \\
\text { is relevant to understanding issues as diverse as the meaning and direction of contemporary } \\
\text { democracy, the human dimension of economic development, conceptions of social justice, public } \\
\text { policies and private initiatives to solve more serious social problems, such as hunger and violence. } \\
\text { Today the debate on inequality has revolved around what would be its main dimensions, what } \\
\text { would be socially justifiable or acceptable levels, what are its main determinants, and what are the } \\
\text { best ways to combat it. Sociology of work and education, as well as all its ramifications, play a } \\
\text { central role in this debate. }\end{array}$ \\
\hline
\end{tabular}




\begin{tabular}{|c|c|c|}
\hline INSTITUTION & AREA & SUMMARY \\
\hline $\begin{array}{l}\text { State University of } \\
\text { Campinas }\end{array}$ & Culture & $\begin{array}{l}\text { This area covers a wide area of interest regarding the cultural problematic in its historical, theoretical } \\
\text { and empirical meanings. The interests that surround research on culture can be correlated with the } \\
\text { investigation of themes and transformations of contemporary society. In this area are considered } \\
\text { studies that may be considered more classic, such as sociology of literature and art, alongside a } \\
\text { wide range of other themes and problems such as: Brazilian culture, identity, cultural industry, } \\
\text { culture and politics, and intellectual and artistic trajectories. It also includes studies on education } \\
\text { and other intersections between culture and contemporary social processes. In addition, research } \\
\text { and cross-cutting reflections on the production and circulation of cultural ideas and goods, diversity, } \\
\text { peripheries, gender, social memory, human rights (collective memories, colonialism and post } \\
\text { colonialism, State violence, political disappearances, transitional justice, Commissions of Truth) } \\
\text { subjectivities and capitalism. The spectrum of themes provides the possibility of theoretical and } \\
\text { empirical studies regarding the meaning of the term culture and at the same time aims to stimulate } \\
\text { reflections on the social processes characteristic of contemporaneity. }\end{array}$ \\
\hline
\end{tabular}

Federal University of Grande Public Policy, Social Theory and Collective Action Dourados
This area develops research on public policies and their consequences for the social organization of the various sectors of civil society, and the way in which social theory assigns it meaning. In this sense, it seeks to deepen the reflection on the impacts felt in the groups and in the social classes, derived from the actions of the State, as well as the influence of the collective action of these groups for the design of the public policies. Understanding the changes in the pattern of relations between society and state and investigating the ways in which social theory has interpreted such processes are objectives of this area. In this context, the various manifestations of social movements and civil organizations are questioned before the State, both in its federative structure and in its manifestation in the form of local power. Among the various public policies, this area problematizes, among others, those focused on education and the world of work, both in the countryside and in the city.

Federal University of $\quad$ Body, culture and knowledge
Alagoas

Alagoas

This area aims to discuss the experiences and manifestations of affections, symbolic expressions and thinking in various contexts and resulting from multiple social phenomena, based on traditions of the Sociology of the Body, Culture and Knowledge. Concerns unfold in the following themes: education and teaching of sociology; intellectuals and social thought; body, gender and sexuality; intergenerational experiences; symbolic and digital goods markets; consumption and cultural policies.

Federal University of Mato Society, culture and power Grosso

The area brings together anchored research in the classical theoretical tradition and in the contemporary approaches to Sociology, in order to deepen the critical reflection on the Brazilian State and society in the more global process of formation and development of the modern order, focusing on theoretical studies and empirical, preferably, on the Midwest and Amazon region. It intends to gather investigations that approach the social processes of configurations and reconfigurations of the power and the culture in Mato Grosso. At the regional level, themes related to the social dynamics of agroindustrial cities and cities where traditional economic activities predominate and experience the advance and presence of agribusiness, microregions with presence of traditional populations and the metropolitan region around the state capital. Seeking to train teachers and the different research agendas, the area gathers the following themes: (1) Culture, diversity and globalization; (2) New ruralities, processes of occupation of spaces and new mechanisms of urbanization and the environmental issue; (3) Reconfigurations of urban spaces, power and new social actors; (4) Education, Teaching and learning processes, teaching, professional socialization, science and technology; (5) Sport, body and identities; (6) Family, health and gender, gender violence, sociology of the body and health; (7) Public policies, State and government, Power and political relations, (8) Conflict, criminal violence, Judiciary, Public security systems, (9) Metatheorical foundations of sociology, sociology of music; (10) Occupations, professions, organizations, beliefs.

Federal University of Minas Sociology of inequalities and stratification Gerais Gender inequalities; Color/race and/or ethnic inequalities; Class Inequalities; Inequality in Health; Inequalities and Public Policies; Stratification and educational mobility and in the labor market.

UFPR Culture and Sociabilities

It articulates interdisciplinary perspectives based on empirical research in dialogue with classical and contemporary sociological theoretical production, involving studies already established in the fields of sociology of culture, knowledge, Brazilian social thought, as well as studies of gender, sport, health, images and imagery. It involves a broad scope of reflections that go from structures and institutions to the dimension of agents' subjectivity, seeking to articulate the field of ideas, values, perceptions, between practical expressions and the representations of the social world. Thematic axes: a) Culture, communication and sociabilities: it is dedicated to the studies on processes of production, diffusion and consumption of goods and cultural manifestations in the contemporaneity. It includes subjects from the field of Sociology of Culture, Communication, Music, Image and Imaginaries, Health and Sociology of Sport; b) Production and circulation of social thought: it is dedicated to the sociological analysis of the conditions of production of social and sociological thinking, as well as the analysis of the limits and possibilities for its circulation, whether in the publishing market, the artistic milieu or in the school system. It also deals with epistemological areas and perspectives such as Sociology of Knowledge, Historical Sociology, Intellectual History, among others; c) Gender, body, sexuality and health: develops research with analytical references of gender, sexuality, body, health, culture and sport. It includes experiences of the subjects with networks of scientific and biotechnological knowledge, with policies of body and rights generation, medicalization, reproduction of life, sexes, corporalities and health. It deals with standardization processes in different areas.

Source: authors (2019). 
This second framework leads us to come up with the issues that were previously pointed out by Sobral (2013), which indicated that education persists as a theme in the research agenda of Brazilian sociology, but is also linked to other major topics that also include education. We can raise two hypotheses for this question: a) that this scenario reflects the growing diversity of issues and the fragmentation of the research agenda of the social sciences as a whole; b) that the programs tend to develop quite broad research areas, following the guidelines of CAPES and thus allowing the incorporation of a more significant number of researchers in their staff.

Thus, the data reveal a significant question: that the widely held statement that education is a «minor» element in the sociology agenda is at least imprecise since the present survey highlights a significant presence of research areas that dialogue with this issue mostly absolute of the area's programs. The figures can help to demonstrate such a scenario: in 2018 CAPES analyzed 51 postgraduate programs in the field of sociology; this is the variety of PP in social sciences, sociology and those of a hybrid character; among these, we have 22 programs specifically in sociology; and in the context of these $22 \mathrm{PP}$ in sociology, 14 present research areas directly or indirectly linked to education, representing approximately $64 \%$ of sociology programs.

We can affirm, therefore, that education is a consolidated theme in the programs of sociology in Brazil, although the occasional presence of references to the educational question in some menus may indicate the presence of few, or often a single teacher who is dedicated to this thematic.

\section{The Academic Production on Education in the master's and doctorate courses in Sociology}

As previously indicated, we surveyed the total production of articles published between 2013 and 2016 (the period of the last four-year evaluation) in the sucupira platform, including publications of both teachers and students and limiting the work exclusively to the productions in scientific journals. This cut led us to an amount of 2,500 published articles, inserted in the scientific journals of the most diverse layers of the qualis.

As we look more closely at articles, it was observed that 228 of them are related to the educational theme, which represents $9 \%$ of the works published in this quadrennium by such masters and doctoral programs. Here again, we can return to the argument that the simple assertion that education would be a forgotten object of sociology is false evidence since sociologists continue to produce on this subject, which is done from the most different approaches.

We are analyzing the production of those programs that have indicated of research areas on education or that at least dialogue with education, but we must not forget that they are the majority among the masters and doctoral programs in sociology. It is possible to suppose that even in the other programs there may be bibliographic productions in this area and that in many cases these productions emerge related to different themes that occupy the central axis of the research agenda of the teachers of these programs.

The increasing diversity and fragmentation of the sociology research agenda would not allow us to affirm the existence of a robust prevailing thematic in Brazilian sociological production. However, we can observe themes that appear as «classics» and that often arise in the productions of the Sociology programs, among them would be education.

8 Qualis is the qualitative evaluation system of national and foreign journals in which Brazilian researchers published, being used as a parameter in the evaluation process of the PP by CAPES. 
Between 2013 and 2016, in the articles published in journals, the 14 postgraduate programs in sociology analyzed here published articles on education as follows, when read in order by absolute number of articles: University of Brasilia with 32 articles (equivalent to $11 \%$ of the production of this institution in this period); University of São Paulo with 28 (or 9\% of its production); Federal University of Rio Grande do Sul also with 28 articles (9.5\% of its production in the corresponding period); State University of Rio de Janeiro with 23 (or 10\% of its total production); Federal University of Pernambuco with 21 articles (or 10.5\% of its own production); Federal University of Goiás with 18 ( $9 \%$ of its production in this quadrennium); Federal University of Piauí with 18 articles ( $25 \%$ of its production); Federal University of Paraná with 17 (6.5\% of its total production); Federal University of Sergipe with 16 (equivalent to $15 \%$ of its production); State University of Campinas with 8 (or $3 \%$ of its production in the period); Federal University of Grande Dourados also with 8 (or 13\% of the production of this program); Federal University of Mato Grosso with 5 articles (which constitute $100 \%$ of its production in this time interval); Federal University of Minas Gerais with 4; and Federal University of Alagoas with 2 articles (or $2 \%$ of its production).

The above-mentioned web brings with it not only the relation between the total number of articles published and those articles that dealt with the themes of education, but it also gives rise to debates about the place that education occupies in each of these programs, in a more specific way, and more generally around quantitative and qualitative differences in the academic production of postgraduate programs (Almeida \& Guimarães, 2013).

The work of searching the 228 articles and subsequent reading of their abstracts allowed the construction of the following corpus of analysis: from the 228 articles, 2 texts were discarded for their unavailability on the Internet; 18 other writings have appeared as distinct types of academic texts and therefore have been grouped into a category called «Others», since they are reviews, dossier presentations, debates, etc.; and finally our main group of articles analyzed corresponds to a total of 208 papers.

When we understand that the texts that make up the category «Others" are part of the production of the Sociology programs analyzed, even though they are not adequately articles, we briefly bring their characteristics here: we are talking about 8 book reviews, 4 interviews, 3 dossier presentations, 1 discussion, 1 text of scientific divulgation and 1 lecture of academic event; the themes that emerge from these texts are diverse, and we have respectively a) affirmative actions, b) teaching sociology, c) inequality (each with $17 \%$ of the total category, that is with 3 texts), soon after we have the theme, d) higher education (with $11.2 \%$ of the category, or 2 texts) and the other topics are each brought by a single text, they are e) education and religion, f) education and difference, g) interdisciplinarity, h) pedagogical practices, i) education and human rights, j) work and science and k) Bernard Lahire.

On the other hand, the work done from the reading of the abstracts of the 208 articles was responsible for the construction of 5 categories of analysis, namely: theme, main discussions, an object of study, subjects of research and space/level. Thus, the exercises of describing and analyzing the data of each of these categories allow us to speak of a research agenda of the sociology of education developed in sociology programs in the new scenario.

Twenty-four themes were counted, revealing the multiplicity of concerns that have moved researchers in the sociology of education in Brazil. Before presenting the data related to these themes, it is necessary to clarify that it was a common factor a single article to connect to more than one subject and the maximum number of links we registered was three different themes. 


\section{Graphic 1. Themes mapped from articles published in scientific journals on the education of postgraduate programs in sociology}

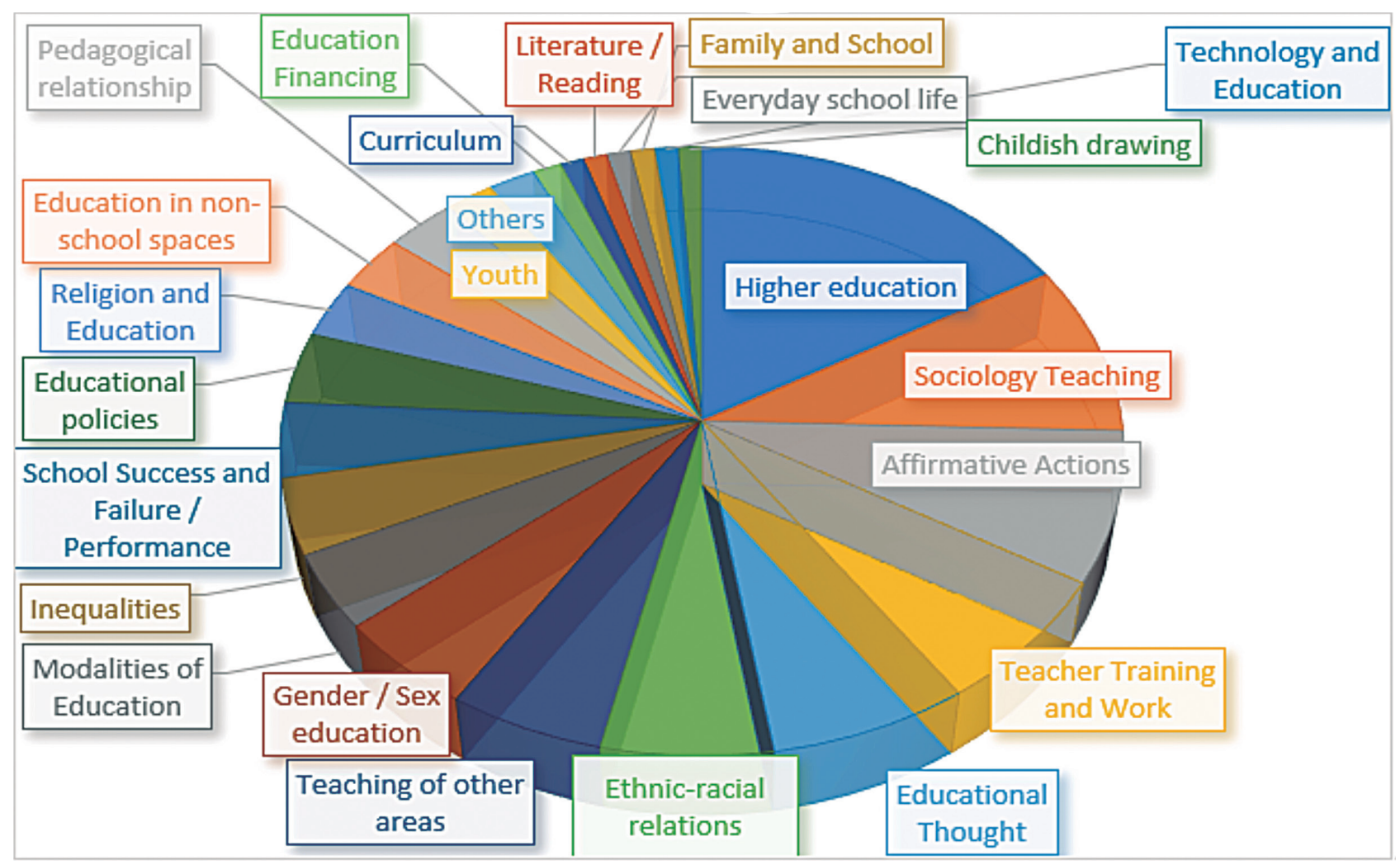

Source: authors (2019).

Graph 1 presents the position of the themes without indicating the respective percentages because our objective is to draw attention primarily to the volume of issues that emerge when the production on the education of postgraduate programs in sociology is questioned. We will hold a debate that combines the category of the theme with the category of the main discussions, to connect them and thus demonstrate how each theme has been approached in the literature coming from the programs analyzed here.

Higher education is a topic of greater expressiveness between 2013 and 2016 with $16.5 \%$, which seems to indicate a priori confirmation of Martins and Weber's (2010) argument that in the «division of labor» between the areas of education and of sociology is based on the primacy of the objectification of higher education by the sociology - assertive that we will return to later. The topic of higher education brings as main discussions issues such as university models and concepts; university and globalization; expansion and internalization; teaching; postgraduate studies; relationship between market and university; social origin, inequality and performance in this level of education; relationship between religion and university and the question of secularity; Africans and Afro-Brazilians in higher education, both as students and as teachers; research, productivism and internationalization; extension actions; distance learning; evaluation; and gender. It is interesting to note how this degree of education has been transformed into a meaningful study/research theme for the sociology of education over the years since it is once again at the forefront of this field.

The teaching of Sociology composes here the second theme with the highest number in the articles analyzed, with $9 \%$ of the total. This finding makes sense in the importance that this theme has been 
receiving in the Brazilian academic field in recent years and seems to prove the following statement by Oliveira (2015:16):

\section{(...) the transformations experienced in Basic Education have direct impacts on the teaching of Social Sciences at the undergraduate level, as well as on the research carried out at the Postgraduate level, which includes both the Postgraduate Programs in Social Sciences/Sociology and the Postgraduate Programs in Education.}

Within the main discussions that mark this theme we have: the role of sociology in high school; pedagogical practice and mediation, didactic strategies and resources; training of sociology teachers; sociology in the university entrance exam; sociology in the curriculum; didactic books; conceptions in the teaching of sociology; Institutional Program of Initiatives for Teaching (PIBID); and academic production on the teaching of sociology.

Soon after, we have the theme of affirmative action, with $8 \%$ of the total articles, whose main discussions revolve around the following issues: racial quota system and transformations in higher education; race, identity and quotas; theoretical contributions on affirmative action; Liberalism and affirmative action; thesis of racial democracy; media and racial quotas; racism and affirmative action; quotas in the governments of the Workers Party (PT); legal issue of affirmative action; quotas, inequality and justice; arguments against quotas; affirmative actions in the military dictatorship; students approved by the system of racial quota and prejudice in higher education. It is worth subverting the order here at this time to promote a correlation between the theme of affirmative action and the theme of ethnic-racial relations (the latter is the 6th theme following Graphic 1 and adds $6 \%$ ): while affirmative action is naturally focused on higher education, the issue of ethnic-racial relations has a more significant expression in the school context, but together these themes account for 14\% of all articles and tell us about the emergence of research problems related to debates about color, race, ethnicity, prejudice, racism, racial difference and inequality and their relation to education.

In this scenario teaching of sociology and affirmative actions are two significant examples of the emergence of specific research agendas since the mid-2000s since these same themes did not appear with the same force in the studies of Neves (2002) and Martins and Weber (2010).

The theme of teacher training and work and the topic of educational thought appear with $7 \%$ each. The first one being marked by discussions about continuing education, teacher training in sociology, and issues such as professional development, illness, precariousness, professionalization and gender; while the second brings discussions about theoretical issues and authors who have focused on education, such as Pierre Bourdieu, Emile Durkheim, Max Weber, and Bernard Lahire.

In turn, the theme of ethnic-racial relations, mentioned above when correlating with affirmative actions, presents as main discussions: Law No. 10.639/2003; racial prejudice in school; the role of the teacher in the context of ethnic-racial relations; racial composition in schools; inequality and discrimination; racial identity; African literature, identity and decolonization of school curricula; relationship between prejudice and school performance; and the right to education for ethnic-racial minorities. On the other hand, the theme «teaching in other areas» also presented in Graphic 1 appears with 5.5\% and brings discussions on the specifics of teaching geography, chemistry, physics, mathematics, history and English language in primary and secondary education, as well as teaching music, nutrition and social psychology in higher education. Continuing the descriptive movement, we have gender/sex education, which with 
$5 \%$ of the total articles is a theme very similar to the issue of ethnic-racial relations, because it focuses primarily on primary and secondary education and brings discussions around differences, inequalities, and prejudice.

Briefly, we will present the other themes and their discussions: modalities of education with $4 \%$ of the total brings discussions about inclusive education, quilombola education, rural education, and youth and adult education; inequalities, with $4 \%$ and main discussions about the relationship between social class origin and school performance; school success and failure/performance, with $4 \%$ and debates about school failure, school abandonment, social determinants and their relation to performance; educational policies appears with 3.8\% and goes through the different levels of education; religion and education, with $3 \%$ and main discussions in the relationship between religion and university and in the debate on religious teaching in the National Curricular Common Basis (BNCC); education in non-school spaces, with $3 \%$ bringing spaces such as penitentiaries, military academies, hospitals, and museums; pedagogical relationship (3\%), marked by discussions such as meaningful learning and pedagogical communication; youth $(2 \%)$, with discussions about young people's school experiences; others $(2 \%)$, a category composed of themes such as the elderly and the relation between school and the media; education financing $(1.2 \%)$ privileges discussions about the quality of education and the control of accounts; and finally, with $1 \%$ each, we have the themes of curriculum, literature/reading, everyday school life, family and school, technology and education and childish drawing.

In addition, we understand that the emergence of specific themes relates to changes in the level of educational policies that directly influence school reality. From this, we mean that the research agenda of the sociology of education is becoming a process that seeks to provide answers to questions that arise in the debate of the public sphere. Moreover, the multiplicity of the themes we have just presented is indicative of the relations between already established themes in the field of educational sociology and emerging themes - relationships that tell us about the hierarchy of legitimate or unworthy objects in the scientific field (Bourdieu, 2013).

To complement our look at this scenario of the themes that have been privileged in the sociology of education developed in the programs of sociology in Brazil, we occupy from here the other categories that we announced at the beginning of this topic: study objects, subjects, and the spaces/levels.

With the data on the subjects, which we have discussed so far, we were interested then to understand through which objects of study these themes were questioned by the researchers of the programs that we are analyzing. Graphic 2 shows an arrangement of the objects to demonstrate their recurrence: 


\section{Graphic 2. Study objects mapped from articles published in journals on education of postgraduate programs in sociology}

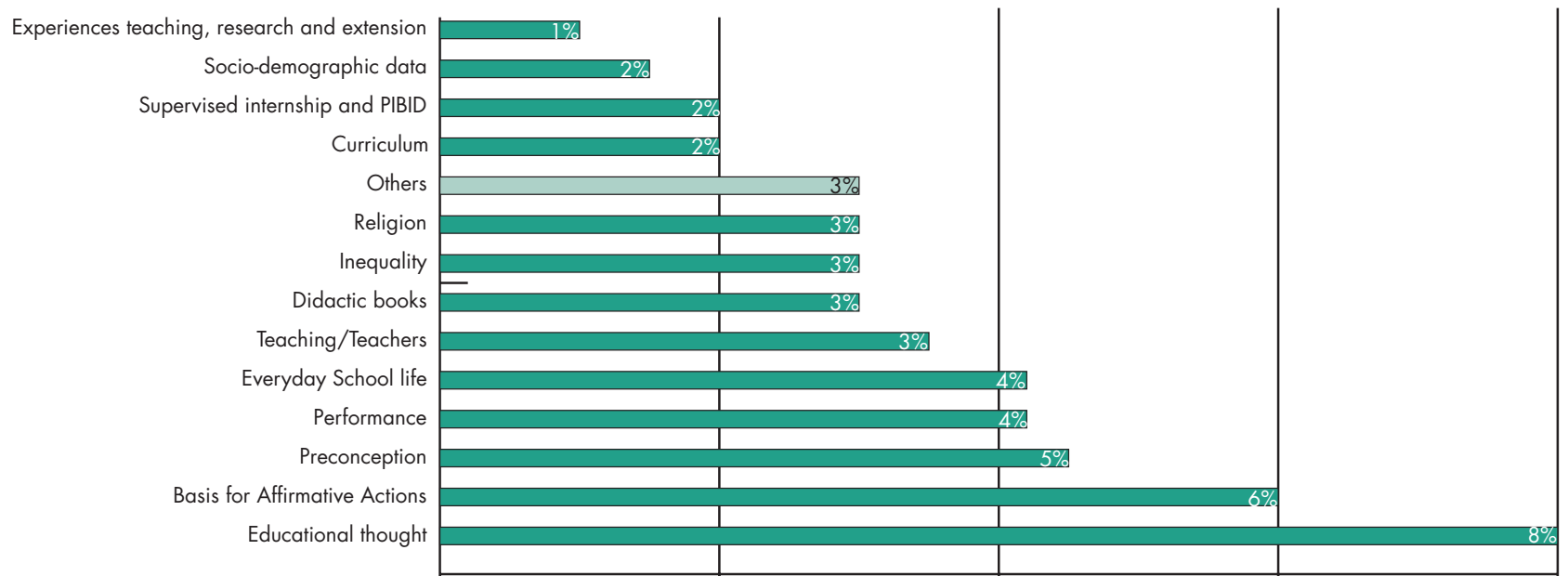

Source: authors (2019).

The 24 themes that mark the production of sociology programs were developed through the objects presented in the graph above. It is worth mentioning here the taking of pedagogical practices as the principal means of investigating sociological problems in the sociology of education, followed by representations and perceptions, which in turn include conceptions and attitudes of the educational subjects in front of the most different elements that emerge from the themes.

In addition to this diversity of study objects, we highlight the following issues: the models of education, institutions and courses go through primary and secondary education, higher education and nonschool spaces; with respect to the trajectories, it is necessary to emphasize that the articles basically bring three types of trajectories (personal/familiar, school and professional) and in some cases correlate these types; what we call here «bases of affirmative action» is formed by laws, public debates, discourses, and theories that guide affirmative actions, finding here favorable and contrary positions; in the term «prejudice» situations and experiences are condensed; in the category «performance» we have the instances of students, institutions, cities, and states; in «others», after all, we have experiences of migration of Brazilians in Rome and Barcelona and the aging process.

Advancing in the exercise of analyzing the 208 articles, the subjects of research contemplated in this production were mapped - it is essential to clarify that some texts have announced more than one group of subjects. We have the following picture: $4 \%$ are «school subjects,» among whom we have students (68 references), teachers (54), school/university subjects in general (42) ${ }^{9}$, and managers (7) respectively; $4 \%$ are «non-school subjects», namely the elderly, resident doctors, women in prison, young people in the CASA Foundation, multilateral agencies, NGOs; $16 \%$ comprised the «not applicable» subcategory, which mainly condenses theoretical essays and policy/document analyses; and $6 \%$ form the «othen» subcategory, among which we have union leaders, entrepreneurs, state secretariat of education and the State as a social agent. Therefore, it is possible to establish a direct relationship between the themes of the articles and their subjects of research, since the school subjects, who represent an absolute majority, are the main actors of the problems contained in these themes.

9 This subcategory was created to serve articles that generally indicated that your target audience in the study or research were subjects of a particular school or university. 
Our last category concerns the space/level where the studies and researches that originated the articles that we are analyzing have been developed. From the data discussed so far, two questions emerge a) a portion of the texts does not fit this discussion because they are mainly theoretical essays and b) in some cases, more than one space was indicated.

\section{Graphic 3. Spaces/Levels mapped from articles published in periodicals on education of postgraduate programs in sociology}

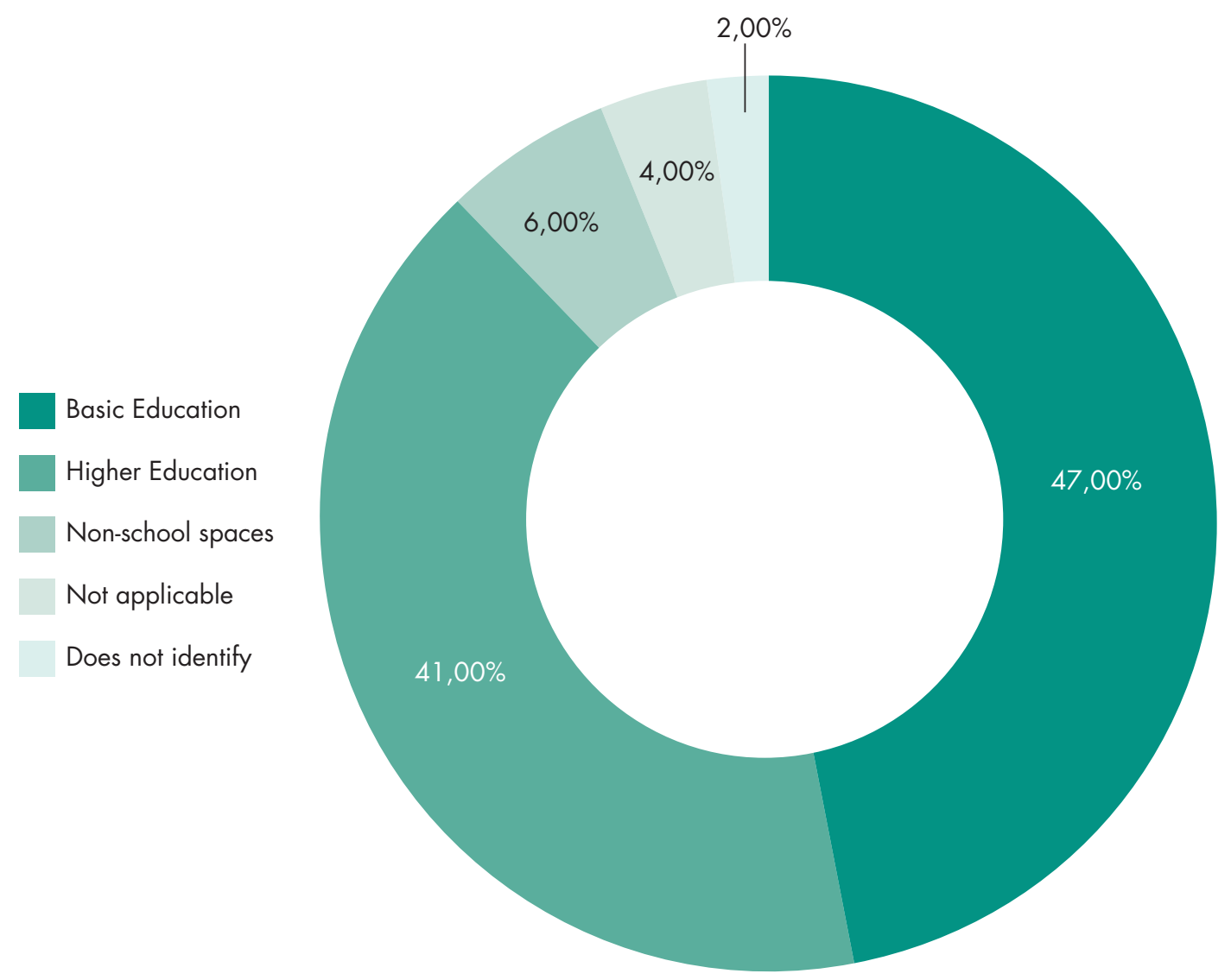

Source: authors (2019).

The exercise of unraveling the data in the graph above allows us to suggest the following settings: primary and secondary education is the main level of national education on which the studies and investigations of researchers who study education from postgraduate programs in sociology are developed, at this level, mentions respectively the school in the general sense (57 occurrences) (30), primary education (9), early childhood education (6) and youth and adult education (2); higher education appears not far from primary and secondary education, with a difference of 6 percentage points, and the mentions, in this case, include higher education/university in general (85), distance education at this level of education (3) and postgraduate studies (2); non-school spaces include a prison unit, NGO, museum, hospital, military academy, quilombola community, and company.

Graphic 3 presents fascinating data for our debate because it allows us to resume a discussion that we began in the description of the first category [the themes]: the division of academic work between sociology and education in the scope of the sociology of education in Brazil. The assertion, therefore, that the sociology of education produced within sociology would be more centered on studies on higher education (Martins \&Weber, 2010) today needs further examination. In fact, as we have shown in the scope of 
the themes, higher education is the main topic in this field, but when we confront this question with the data about the levels of education on which the research is carried out, primary and secondary education emerges, which allows us to reflect in the following directions: a) as a level of Brazilian education, higher education was itself a subject of the sociology of education; b) primary and secondary education, also as a level of Brazilian education, does not in itself constitute a theme of the sociology of education, it is, on the other hand, «diluted» in many of those themes that make up our Graph 1.

In this sense, one of the main findings of our study was to understand the place of the primary and secondary education in the production and the agenda of the sociology of education developed by the researchers of the postgraduate programs in the area of sociology. The primacy of higher education has been taken almost as a consensus in the specialized literature, but the most recent scenario has allowed us to observe the concern with the issues related to the most different spheres of primary and secondary education. The debate about teaching sociology in high school has certainly been a driving force for this renewed interest in this educational level.

It should also be noted that, in view of the presence of intensely consolidated researchers with an intense international circulation, through doctoral courses (full or sandwich), post-doctoral offices, etc. (Oliveira \& Silva, 2016), the internationalization of the production of these researchers is still timid since only 19 articles were published in a foreign language in this amount, 16 in the English language, 2 in Spanish and one in French, that is to say only around 8\% of articles were published in a foreign language ${ }^{10}$.

\section{Final considerations}

Understanding the place of education within sociology has been an exercise in self-reflection that researchers in this field have been systematically confronting since the 1980s. The expansion and diversification of the higher education and the academic field experienced in Brazil in the last decades, accompanied by the vast possibilities of knowing the scientific production, allow a constant self-reflection, of which the present article is a product. When we examined the production of the sociology of education in the recent panorama, we approached postgraduate programs in the field of sociology and mapped its research agenda in the last four years of CAPES analysis (2013-2016) through articles published in journals.

First, we demonstrate how the research areas of the postgraduate programs in sociology are capable of revealing the place of education within sociology, and in this sense, there has been a tendency to incorporate education directly or indirectly in these programs, since of 22 sociology programs, 14 have some connection with education. The more traditional programs and the newly created programs share this tendency to integrate into their scopes demands for debates, discussions, and research on education. In addition to presenting an update of these data about graduate programs (Oliveira \& Silva, 2016), the innovative character of this article was in charge of examining the recently designed research agenda for the production of these programs.

Thus, it was ratified that education continues as an essential theme for sociology, as well as the mapping of «what» has been researched in this space. It can be affirmed that the sociology of education de-

10 We do not want to deny that the process of internationalization of academic production goes beyond publication in foreign language journals, since there are Latin American and even Portuguese journals in which researchers in the field of sociology of education also circulate, we indicate here as a relevant issue to capture the internationalization of production the publication of articles in a foreign language. 
veloped in the field of sociology is composed of a multiplicity of themes and objects of research and that the discussions that surround these themes are related to the main national questions about education, but also the debate about the differences (color, race, gender, class). Higher education confirms itself as the main theme of the sociology of education within the scope of sociology; however, it reveals a need to deepen its understanding in view of the place that basic education, even «diluted» in other themes, has been gaining in recent years. In addition to the strict topics, it is possible to affirm that the issue of inequality continues to mark production in the sociology of education, since a significant part of the articles analyzed here, even though they do not refer explicitly to inequality, deal with asymmetries of various orders.

\section{Bibliographic references}

Almeida, Ana Maria Fonseca y Hey, Ana Paula (2018): "Sociologia da Educação: olhares sobre um campo em ascensão" en Sergio Miceli y Carlos Benedito Martins (orgs.): Sociologia Brasileira Hoje. São Paulo: Ateliê Editorial.

Almeida, Elenara Chaves Edler y Guimarães, Jorge (2013). A pós-graduação e a evolução da produção científica brasileira. São Paulo: Editora Senac.

Bourdieu, Pierre (2013): "Método científico e a hierarquia social dos objetos" en Maria Alice Nogueira y Afrânio Mendes Catani (orgs.): Escritos de Educação. 4th ed. Petrópolis, RJ: Vozes.

Cunha, Luiz Antônio (1992): “A educação na sociologia: um objeto rejeitado?”. Caderno Cedes, 27, 9-22.

Lima, Jacob Carlos y Cortes, Soraya M. Vargas (2013): “A sociologia no Brasil e a interdisciplinaridade nas ciências sociais". Civitas, $13(2), 416-435$.

Martins, Carlos Benedito y Weber, Silke (2010): "Sociologia da educação: democratização e cidadania" en Carlos Benedito Martins y Heloisa Helena T. de Souza Martins (orgs.): Sociologia. São Paulo: Anpocs.

Meucci, Simone (2015). Artesania da sociologia no Brasil: contribuições e interpretações de Gilberto Freyre. Curitiba: Appris.

Neves, Clarissa E. Baeta (2002): "Estudos sociológicos sobre Educação no Brasill” en Sergio Miceli (org.): O que ler na Ciência Social brasileira (1970-2002). São Paulo: Anpocs; Editora Sumaré.

Oliveira, Amurabi (2015): "Um balanço sobre o campo do ensino de sociologia no Brasil”. Em Tese, $12(2), 6-16$.

Oliveira, Amurabi y Silva, Camila Ferreira (2014): "Mapeando a sociologia da educação no Brasil: análise de um campo em construção”. Atos de Pesquisa em Educação, 9 (2), 289-315.

Oliveira, Amurabi y Silva, Camila Ferreira (2016): "A sociologia, os sociólogos e a educação no Brasil". Revista Brasileira de Ciências Sociais, 31 (91), 1-15.

Silva, Camila Ferreira y Alves, Mariana Gaio (2018): "As aspirações dos aprendizes: doutorandos em educação no Brasil”. Cadernos de Pesquisa, 48 (167), 280-308.

Silva, Graziella Moraes Dias (2002). Sociologia da sociologia da educação. Caminhos e desafios de uma policy science no Brasil (1920-79). Braganca Paulista: Universidade São Francisco. 
Sobral, Fernanda (2013): “A educação na pós-graduação em sociologia: um objeto escondido?”. Estudos de Sociologia [online], 1 (19), 1-15.

Weber, Silke (1992): “A produção recente na área de educação”. Cadernos de Pesquisa, 81, 22-32.

\section{Biographical notes}

Amurabi Oliveira es doctor en Sociología de la Universidad Federal de Pernambuco. Profesor del Departamento Sociología y Ciencia Política en la Universidad Federal de Santa Catarina (Brasil) e investigador en el Consejo Nacional de Desarrollo Científico y Tecnológico. Actualmente es profesor visitante en la Universidad Autónoma de Barcelona.

Camila Ferreira da Silva es doctora en Ciencias de la Educación por la Universidad Nova de Lisboa y postdoc en Sociología Política de la Universidad Federal de Santa Catarina (Brasil). Profesora en la Facultad de Educación en la Universidad Federal del Amazonas (Brasil). 